\title{
Vestidos de papel: representaciones de la moda en la prensa de Buenos Aires, décadas de 1860 y 1870
}

\author{
[Paper Dresses: Representations of Fashion in Buenos Aires' Press, \\ 1860s and 1870s]
}

\author{
Teresita Garabana \\ (Instituto de Altos Estudios Sociales, Universidad de San Martín / \\ Consejo Nacional de Investigaciones Científicas y Técnicas, Argentina) \\ trst12@gmail.com
}

\begin{abstract}
Resumen
El artículo analiza representaciones de la moda en un conjunto de periódicos publicados en Buenos Aires en las décadas de 1860 y 1870. Tras describir los rasgos principales de la prensa desarrollada en este período, el trabajo analiza las ilustraciones de moda -figurinesque circulaban en algunos periódicos, y los textos que convivían con dichas imágenes. El artículo explora las ambigüedades y tensiones entre textos e imágenes. Así, se argumenta que la moda ocupó un lugar renovado dentro de la prensa: los figurines no solo transmitían las modas parisinas en Buenos Aires, sino que comunicaban un estilo de vida asociado a lo burgués-femenino, mientras que los textos que los describían buscaban adaptarlos a la realidad local. Asimismo, en las crónicas de la moda, otras voces advertían acerca de los peligros que la moda y el consumo de vestimenta podría traer para las mujeres y sus familias.
\end{abstract}

Palabras claves: Moda; Figurines; Prensa Periódica; consumo; Buenos Aires.

\begin{abstract}
The article analyzes representations of fashion on a set of newspapers published in Buenos Aires in the 1860s and the 1870s. After describing the main characteristics of the press developed in this period, the paper focuses on analyzing the fashion illustrations that were published in some newspapers, and the texts that coexisted with those images. The article explores ambiguities and tensions between texts and images. Therefore, we argue that fashion had a renewed place on the press: fashion illustrations not only transmitted Paris' fashion in Buenos Aires, but also communicated a life-style associated with the bourgeoise-feminine; meanwhile the images' descriptions attempted to adapt them to local reality. Additionally, in the chronicles about fashion, some other voices warned about the dangers that fashion and its consumption could bring to women and their families.
\end{abstract}

Keywords: Fashion; Fashion Illustration; Press; consumption; Buenos Aires.

Recibido: $26 / 01 / 2020$

Evaluación: 07/07/2020

Aceptado: 21/08/2020

Anuario de la Escuela de Historia Virtual - Año 11 - $\mathrm{N}^{\circ} 18$ - 2020: pp. 107-132.

ISSN: 1853-7049

http://revistas.unc.edu.ar/index.php/anuariohistoria 
108 | Vestidos de papel: representaciones de la moda...

\section{Vestidos de papel: representaciones de la moda en la prensa de Buenos Aires, décadas de 1860 y 1870*}

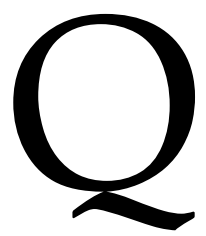

uienes vivieron en Buenos Aires entre 1860 y 1880 fueron testigos de un conjunto de transformaciones que dejarían atrás a una ciudad colonial, mientras la preparaban para convertirla en una capital cosmopolita. Una de las características distintivas de la ciudad en este periodo fue su crecimiento demográfico: mucho antes de ser declarada capital de la República, Buenos Aires ya era la localidad más densamente poblada del país y la más atractiva para los inmigrantes que llegaban desde mediados de siglo (Míguez, 2008, p. 179). Con una tasa de crecimiento demográfico cercana al 5\% anual, para 1870 la mitad de la población porteña había nacido en Europa (Hora, 2010, p. 131). Lejos de ser un recipiente pasivo de la riqueza generada en el campo, la ciudad se configuraba como un importante proveedor de bienes y servicios para un mercado interno en permanente expansión.

La llegada continua de inmigrantes transformó por completo el paisaje social, porque los nuevos habitantes venían de diversos lugares, cargados de expectativas múltiples. Así, viejas y nuevas tensiones y desigualdades tendían a confundirse o superponerse y se iba perfilando una estratificación, cada vez más compleja, que no podía ya reducirse a las antiguas categorías de "gente decente" y "plebe" (Sábato, 2004, p. 45). Paralelamente, la prensa periódica asistía a un desarrollo sin precedentes (Sábato, 2004; Prieto, 2006). La incorporación de los servicios telegráficos posibilitaba, por primera vez, una comunicación "universal" (Caimari, 2015, pp. 125-146). En estas décadas surgió la figura del editor de periódico y el oficio de periodista (Sábato, 2004, p. 72), a los que se sumaría luego el de litógrafo. La imagen, en efecto, fue ocupando un espacio cada vez mayor en la prensa: las nuevas tecnologías que habilitaron los procesos de reproducción, le otorgaron un lugar cada vez más preponderante dentro de las publicaciones, desafiando el rol del texto. Así, la cultura impresa devino, también, una cultura de lo visible (Szir, 2009).

En la prensa ilustrada de estas décadas la moda ocuparía un lugar privilegiado que puede constatarse tanto por la abundante presencia de imágenes sobre el tema figurines- como por las crónicas de la moda con las que dichas imágenes convivían. El abordaje de las fuentes nos permite señalar que los figurines, en las décadas de $1860 \mathrm{y}$ 1870, contribuyeron a crear nuevas ansiedades en relación al consumo de vestimenta.

\footnotetext{
* Una primera versión de este artículo formó parte de mi tesis de Maestría en Investigación Histórica (Universidad de San Andrés). Agradezco los comentarios y sugerencias que recibí de Lila Caimari, Marisa Baldasarre y Fernando Rocchi durante la defensa.
} 
No obstante, estas imágenes convivieron en la prensa con otros discursos menos celebratorios de la moda, que advertían sobre los peligros de sus excesos.

A partir de la observación de un conjunto de fuentes hemerográficas, el objetivo de este artículo es analizar estas representaciones visuales y escritas de la moda en la prensa de Buenos Aires. Cuando hablamos de representaciones tomamos el concepto de Louis Marin (1993), quien pone en consideración la dimensión transitiva de los objetos, esto es, su posibilidad de hacer presente lo ausente. La representación da a ver el objeto ausente -sea una cosa, un concepto o una persona- a través de una imagen capaz de representarlo. Desde ese punto de vista, el presente artículo hará foco en los discursos e imágenes referidas a la moda que están presentes en las publicaciones periódicas, sin desconocer que se trata de textos elaborados con una intencionalidad, los cuales no "reflejan" la realidad de una época, ni mucho menos la experiencia histórica de los sujetos. En tal sentido, el objeto de estudio del presente artículo es la prensa de moda y no sus posibles o potenciales consumidores.

Por otra parte, suscribimos a la diferenciación que Joanne Entwistle (2002) realiza entre los términos "moda" y "vestimenta", ya que estos suelen confundirse o usarse como sinónimos. Si bien es evidente que todas las personas necesitan cubrir sus cuerpos con vestimenta, no toda vestimenta es sinónimo de moda. La moda, señala Entwistle (2002, p. 56), puede ser concebida como un sistema de vestir que solo existe en sociedades donde la movilidad social es posible, y que involucra una lógica de cambio regular y sistemático. En el presente artículo, pues, cuando hablamos de "moda" nos referimos a aquellas columnas e imágenes que se refieren al tema en la prensa de Buenos Aires, sin ignorar que estas representaciones no necesariamente revelan cómo era en realidad la vestimenta de quienes habitaban la ciudad.

Como veremos, los contenidos sobre moda se dirigían de manera contundente al género femenino, y dentro de este, a un tipo específico de mujer perteneciente a la élite. En estas décadas, la élite porteña tenía aún ciertas características de corte antiguo, vinculadas al criollismo. Como señalan Leandro Losada y Roy Hora (2011, p. 622), entre 1860 y 1880 los miembros de este grupo no sentían que su lugar estuviese amenazado, y no parecía tampoco que hubiera aún sectores dispuestos a ocupar ese lugar.

Desde luego, sabemos que no todas las mujeres de Buenos Aires consumían periódicos. En primer lugar, porque en esta época el acceso a la lectura estaba muy lejos de generalizarse: el censo nacional de 1869 señala que, en ese año, solo el 43\% de las mujeres de Buenos Aires sabían leer, mientras que, en 1887, el censo municipal de la ciudad revela que esa cifra solo había ascendido ligeramente, hasta alcanzar al 53\% de las mujeres. ${ }^{1}$ Desde 1824 la alfabetización femenina estaba a cargo, precisamente, de un conjunto de mujeres provenientes de la élite, que operaban en el marco institucional de

${ }^{1}$ Cfr. Primer Censo de la República Argentina, 1869, Buenos Aires, 1872; AA.VV. Censo general de población, edificación, comercio e industrias de la ciudad de Buenos Aires. Tomo II, Buenos Aires, Compañía Sudamericana de Billetes de Banco, 1889 (levantado en agosto de 1887).

Anuario de la Escuela de Historia Virtual - Año 11 - No 18 - 2020: pp. 107-132. ISSN: 1853-7049 
110 | Vestidos de papel: representaciones de la moda...

la Sociedad de Beneficencia, primera institución pública de la que participaban mujeres (Batticuore, 2017, p. 31).

Por otra parte, aunque vinculado al punto anterior, es probable que la mayor parte de las mujeres que vivían en Buenos Aires, entre 1860 y 1880, no contaran con dinero propio para la adquisición de periódicos. No obstante, dilucidar quiénes eran efectivamente las consumidoras de periódicos con contenidos de moda excede los objetivos del presente artículo, ya que las fuentes analizadas no nos permiten realizar aseveraciones al respecto.

En las próximas páginas nos referiremos, en primer lugar, al desarrollo de la prensa en relación a la moda que asistía a una profunda renovación, caracterizada por la creciente incorporación de imágenes en ciertas publicaciones. En segundo lugar, analizaremos las imágenes de moda, teniendo en cuenta las distintas funciones del figurín: transmisión visual de los estilos de vestimenta europeos, pero también instrucción acerca de poses, gestos y comportamientos femeninos. Por último, teniendo en cuenta lo anterior, analizaremos las tensiones entre las referidas imágenes y otros textos, también presentes en la prensa, que advertían sobre los peligros de la moda y su consumo.

Dado el volumen de material gráfico producido en Buenos Aires en este período, resulta imprescindible realizar un recorte que obedezca a la dimensión temática que aquí nos ocupa. Así, nos referiremos a tres periódicos literarios ilustrados -La Flor del Aire (1864); Correo del Domingo (1865-1868) y La Ondina del Plata (1875-1878)- que distribuían figurines de moda con asiduidad. Estas revistas se complementan con otras contemporáneas que, si bien no contenían figurines, publicaban crónicas referidas a la moda y el consumo de vestimenta: La Siempre Viva (1864); La Alborada del Plata (1879) y El Álbum del Hogar (1880). El análisis de este conjunto de fuentes hemerográficas -que, desafortunadamente, no llegan a formar ninguna colección completa- nos permitirá arrojar luz sobre el lugar de la moda en la prensa porteña, en un período en que las ansias por el progreso se tensionaban no solo con las voces que lo consideraban peligroso, sino también con las posibilidades materiales de concretarlo.

\section{Prensa, moda y cultura visual}

Los estudios de la moda constituyen un campo académico interdisciplinario y aún en construcción, abrevado por investigaciones provenientes de la sociología, la literatura, la historia del arte y la nueva historia social y cultural. En Argentina es posible recuperar varios aportes que, de una $\mathrm{u}$ otra forma, dialogan con el presente artículo. ${ }^{2}$

\footnotetext{
2 Por una cuestión de enfoque, se han referido principalmente los trabajos centrados en el siglo XIX y con los cuales este artículo dialoga de forma más directa. Sin embargo, existen numerosos estudios que abordan diferentes aspectos de la moda y la vestimenta en la historia argentina. El libro de la socióloga Susana Saulquin (1990) ofrece una visión de conjunto que ha sido pionera. Más recientemente, cabe mencionar el
} 
Recientemente, se ha publicado una compilación que, a lo largo de sus once capítulos, pone en diálogo herramientas sociológicas con aquellas del diseño de indumentaria y los estudios de género en diferentes momentos de los siglos XIX y XX (Zambrini y Lucena, 2019). ${ }^{3}$ Por otra parte, recuperamos el análisis literario de Regina Root (2014), cuyo libro se centra en la moda como asunto de interés político a lo largo del siglo XIX. En una línea similar, cabe referir el trabajo de Susan Hallstead (2008), que aborda el papel del consumo de moda en la construcción de identidades nacionales entre 1829 y 1880. Desde la historia del arte, Marcelo Marino (2009) ha analizado las representaciones de los peinetones en las láminas litografiadas de César Hipólito Bacle y las prendas impresas elaboradas durante el periodo rosista, tendientes a fortalecer la imagen del "restaurador de las leyes" (Marino, 2013). También, desde la historia social del arte y los estudios visuales, cabe citar el reciente trabajo de María Isabel Baldasarre (2020) sobre el comercio de vestimenta en las grandes tiendas porteñas entre finales del siglo XIX y comienzos del $\mathrm{XX}$, en el que se analiza la confluencia entre prensa ilustrada, comercio y publicidad.

Si bien este artículo se centra en las décadas de 1860 y 1870, es preciso señalar que la moda estuvo presente en la prensa de Buenos Aires desde la primera mitad del siglo XIX. Durante el rosismo, la moda fue percibida, por la generación del '37, como un fenómeno vinculado a la modernidad: autores como Sarmiento y Alberdi la incorporaron a sus escritos, siendo capaces de articular, a través de esta, muchas de las ansiedades relacionadas con la construcción de la nación (Hallstead, 2008, p. 181). El 18 de noviembre de 1837 salía a la venta una gacetilla denominada, precisamente, La Moda, dirigida por Juan Bautista Alberdi. Esta publicación pionera, que contó con veintitrés números, trascendía ampliamente el interés por la vestimenta y apuntaba a acercar las costumbres europeas hacia las tierras locales. En un contexto caracterizado por la censura que imponía el rosismo, la gacetilla condensaba temáticas culturales como música, poesía, literatura y costumbres, aunque contaba con un interés político: detrás de las pretensiones de trivialidad con las que Alberdi buscaba eludir la censura, se escondían sus ideas en torno al progreso (Rodríguez Pérsico, 2003, pp. 279-302). En su primer número, el director señalaba que "la propuesta tiende a reemplazar la costumbre para instalar en su lugar nuevos hábitos que, a su vez, deberán convertirse en costumbre". ${ }^{4}$ Como señala Claudia Román (2003, p. 440), esta publicación había sido

trabajo de María Isabel Baldasarre (2019), sobre los retratos de artistas entre fines del siglo XIX y las primeras décadas del XX; el análisis de Natalia Milanesio (2017), sobre la vestimenta y las preocupaciones de clase durante el primer peronismo y, además, el estudio que Valeria Manzano (2009) realizó sobre los significados del jean para la juventud argentina durante las décadas de 1960 y 1970.

${ }^{3}$ Si bien este libro fue publicado en Buenos Aires, contiene también aportes de autores y autoras de diferentes lugares de Latinoamérica (México, Brasil, Chile y Colombia), constituyendo, por ello, un valioso aporte descentrado: como señalan sus compiladoras, tradicionalmente los estudios de la moda han sido eurocéntricos, y esta lectura dio lugar a interpretaciones despectivas -y equivocadas- en las cuales Latinoamérica se limitaba a "copiar" los estilos europeos.

${ }^{4}$ La Moda, 18 de noviembre de 1837, p. 1. 
112 | Vestidos de papel: representaciones de la moda...

pensada con el objetivo de modificar la conducta de sus lectores, mujeres y varones jóvenes y cultos. La Moda buscaba, sobre todo, imponer nuevos códigos capaces de operar en distintos planos de la vida cotidiana y se ofrecía a lectores y lectoras como una suerte de manual de conducta donde se les explicaba cómo actuar en sociedad (Iglesia y Zuccotti, 1997). En definitiva, esta publicación era la expresión escrita del intento de acercar Europa a América. Así, las referencias a la vestimenta y su uso deben ser enmarcadas en un sentido mucho más amplio, prácticamente como un sinónimo de progreso.

Desde su exilio en Chile, Domingo Faustino Sarmiento se refirió, en algunos de sus textos, a la moda en un sentido similar al de Alberdi: la adopción de un tipo de vestimenta europea -así como el abandono de elementos como el poncho, representativo del gaucho y de la pampa- era una forma de "civilizar" a los pueblos, aunque fuera superficialmente. Sarmiento también enlazaba la cuestión de la vestimenta con otras, y sostenía que el vestir de los pueblos tenía una correspondencia con su grado de civilización y su modo de gobierno:

Los pueblos... descubren su jenio [sic] su espíritu, sus necesidades i su civilización, en la manera i forma de sus equipajes i vestidos. La civilización ha tomado su forma esterior [sic] la misma en todas partes. El hombre culto usa fraque, periódicos, reloj, levita, gobiernos constitucionales donde puede, literatura nacional, silla, ciencias, etc. etc. (Sarmiento,1887, Vol. 1, p. 9).

Con este tipo de afirmaciones, Sarmiento establecía una correlación entre vestimenta y ciudadanía, entre progreso económico y progreso sociocultural. Así, para "civilizarse" las personas tenían que abrazar al mercado como la mejor instancia del sistema democrático en acción (Hallstead, 2008, pp. 182-186). Para los dos representantes de la generación del '37, en definitiva, la adopción de las modas europeas era la forma que podía encontrar una población "atrasada" al momento de "modernizarse". Estos discursos entendían a la moda como sinónimo de vestimenta europea, la cual era, a su vez, sinónimo de novedad y de progreso (Goldgel, 2013, p. 25). Este interés por la moda de parte de los intelectuales rioplatenses se vincula al creciente valor que "lo nuevo" había ido adquiriendo en Hispanoamérica: desde comienzos del siglo XIX, se observa un quiebre en el valor de lo tradicional, asociado a un pasado colonial y de dependencia política. En ese contexto, la invocación de la novedad no solo le asignaba a esta un valor crecientemente positivo, sino que, además, incluía frecuentemente la idea de que lo nuevo tenía un valor por el solo hecho de serlo (Goldgel, 2013, p. 29).

No obstante, a pesar de ciertas continuidades, durante el periodo que analizamos los discursos referidos a la moda y su consumo fueron bastante más ambiguos. Evidentemente, el modelo europeo persistió, pero, a su vez, convivió con otras ideas, que echaban de menos la sencillez criolla de épocas anteriores, y que advertían sobre los peligros que el consumo de vestimenta podía traer para las familias. A mediados de la 
década de 1860, en la prensa porteña comenzaba a cuestionarse cuál debía ser el lugar de la moda en la sociedad: si era realmente un sinónimo de progreso; una forma de direccionar a la población hacia el buen gusto y la civilización; o si, por el contrario, representaba una marca de frivolidad y un camino hacia el derroche y la perdición de las familias.

La historia de la prensa ilustrada porteña en la segunda mitad del siglo XIX es un campo de investigación intensamente indagado, especialmente en la última década (Baldasarre, 2011; Malosetti Costa y Gené, 2013; Szir, 2009, son solo algunos ejemplos). Esto no llama la atención si tenemos en cuenta la variedad y el volumen de publicaciones -con y sin ilustraciones- que florecieron a lo largo de este periodo: entre 1860 y 1880, en un año cualquiera se producían decenas de periódicos. En 1872, por ejemplo, aparecieron 44 títulos nuevos, que se sumaron a los 50 que ya existían en circulación (Prieto, 2006, p. 44). El tiraje de las publicaciones era muy variable y muchas de estas empresas editoriales tuvieron una existencia efímera, pero llama la atención la profusión de los títulos, junto con la variedad de contenidos que estos ofrecían. Si bien la decisión de incluir ilustraciones elevaba los costos, la seducción que implicaba un periódico ilustrado tendía a compensarlos (Román, 2010, p. 65). El consumo de estas novedosas imágenes en Buenos Aires puede definirse, en palabras de Mirzoeff (2003, pp. 17-45), como un "acontecimiento visual", es decir, como una interacción entre los espectadores y aquello que miran u observan. Progresivamente estas imágenes pasaron a formar parte de la vida cotidiana de quienes las consumían.

Como ya se ha señalado, una de las particularidades de las publicaciones ilustradas que analizamos aquí, es que se dirigían, al menos en parte, a un público femenino. Si durante la primera mitad del siglo XIX existen pocas referencias a mujeres lectoras de periódicos y, menos aún, a redactoras (Batticuore, 2017, p. 63), desde la década de 1860 algunos periódicos ilustrados, que se autodenominaban "literarios", se dirigían a lectoras y también contaban con colaboraciones femeninas, especialmente en las secciones referidas a la moda. En la segunda mitad del siglo XIX, tal como analiza Graciela Batticuore (2017, p. 64), comienzan a multiplicarse las representaciones de mujeres lectoras de periódicos, que formaban parte de un público cada vez más diversificado y creciente, capaz de consumir impresos.

Los subtítulos de los periódicos que se analizan en este artículo, expresan una combinación de literatura con otras temáticas como el teatro, el arte o la moda. En el caso de contar con ilustraciones, esa característica era subrayada en el subtítulo: "La Flor del Aire. Periódico literario ilustrado. Dedicado al Bello Sexo. Literatura, sátira decorosa, teatros, modas, variedades" (1864); "La Siempre Viva. Periódico Literario Ilustrado, dedicado al bello sexo argentino, escrito por señoras" y, debajo, como segundo subtítulo, "Literatura, educación, modas, teatros, bellas artes, crónicas" (1864); “Correo del Domingo. Periódico literario ilustrado"; "La Alborada del Plata. Teatros, modas, literatura, artes y ciencias"; "La Ondina del Plata. Revista semanal de literatura y modas" (1875). El Álbum 
114 | Vestidos de papel: representaciones de la moda...

del Hogar (1878), por su parte, aunque se presentaba como un periódico literario, contaba con secciones tituladas "Modas" o "Correrías y Modas". Tanto los textos como las imágenes referidas a la moda, se dirigían continua y exclusivamente al género femenino, reforzando así la naturalización del vínculo "moda-mujer" (Bard, 2012, pp. 11-19).

El tono que adoptaban estos periódicos al momento de dirigirse a sus lectoras buscaba alternativamente seducirlas y educarlas: si bien era fundamental ofrecerles material que les interesara (Vicens, 2014, p. 89), existía una suerte de pedagogía del comportamiento. En reiteradas crónicas de moda, parecía necesario indicar qué debían consumir las mujeres y por qué razones, hasta qué punto y con qué límites. Al mismo tiempo, desde la visualidad, estas imágenes estimulaban el consumo de vestimenta, y lo vinculaban a una sociabilidad burguesa, que en la Buenos Aires de este período sería interpretada con gran sensibilidad.

Estos periódicos cumplían varias funciones: por un lado, eran informantes de todo aquello que merecía ser contado. Abundaban las noticias sobre la Guerra del Paraguay, los textos e imágenes sobre las últimas modas de París, las crónicas locales que relataban los estrenos del Teatro Colón. Asimismo, incluían partituras musicales, novelas distribuidas en sucesivas entregas, poesías y charadas. Por otro lado, estas publicaciones funcionaban como manuales de comportamiento para sus lectores y lectoras mediante textos e imágenes que expresaban cuáles eran las conductas deseables frente a determinadas situaciones sociales, como un baile o un concierto. Así, suscribiéndose a este tipo de publicaciones, las familias porteñas obtenían semanalmente un repertorio general de temas de conversación, una partitura con la que lucirse en el piano frente a invitados, material de ficción cuyas protagonistas trazaban vidas posibles, imágenes de mujeres a las que desear o con quienes identificarse. Al condensar esta variedad de materiales, los periódicos ilustrados operaban como complejos dispositivos culturales.

\section{Imágenes de moda, imágenes de mujeres}

En la segunda mitad del siglo XIX, la cultura de la imagen se fue abriendo paso frente a la palabra escrita en la prensa. Inclusive, es posible hablar de una conversión del mundo -espacios, sujetos, objetos- en material visible y exhibible, de una progresiva, pero inexorable, transformación del mundo en espectáculo (Rodríguez Lehmann, 2017). Los figurines, que surgieron en París hacia mediados del siglo XVIII (Nelson Best, 2019, p. 35), condensaban la capacidad de transmitir la moda parisina en otras partes del mundo de una forma rápida y efectiva. Hasta su invención, en París se elaboraban "Pandoras", pequeñas muñecas vestidas con las últimas novedades, que se enviaban al resto de las grandes ciudades de Europa, a fin de transmitir cuáles eran las modas. ${ }^{5}$ Este proceso,

\footnotetext{
5 Algunos de estos maniquíes en miniatura han sobrevivido en el tiempo y pueden encontrarse en determinados museos. Cabe mencionarse, como ejemplo, los que forman parte de la colección permanente de vestidos del Victoria $\&$ Albert Museum de Londres.
} 
caro y lento, hacía prácticamente imposible la llegada de la moda europea a América, pues aquellos maniquíes en miniatura rara vez cruzaban el Atlántico. A comienzos del siglo XIX, Napoleón prohibía el envío de las Pandoras hacia fuera de Francia, lo que favoreció a las primeras revistas de modas, como el Journal des Dames et des Modes que había surgido en 1797 (Nelson Best, 2019, p. 40). La posibilidad de reproducir las imágenes en publicaciones, proceso que se fue generalizando a lo largo del siglo XIX, habilitó por primera vez la difusión visual de la moda europea a una escala mundial.

Tradicionalmente, tanto la historia como la historia del arte han dedicado poca atención a estas imágenes de gran circulación. Sin embargo, en las últimas décadas, dentro del campo de las humanidades asistimos a un "giro pictorial", lo que ha resultado en una mayor atención sobre las imágenes en tanto documentos históricos; y la inclusión de imágenes que anteriormente no eran consideradas obras de arte (Mitchell, 1996). Asimismo, la actividad del espectador -la visión, la mirada, las prácticas de observación y el placer visual- "puede constituir un problema tan profundo como las formas de lectura" (Mitchell, 1996). En tal sentido, la publicación y circulación permanente de figurines, no solo transmitía qué tipo de vestimenta estaba en boga, sino que generaba un entrenamiento visual acerca de cómo debían verse y comportarse las mujeres.

En París, se han catalogado unos quinientos profesionales dedicados a la elaboración de figurines entre fines del siglo XVIII y comienzos del siglo XX. Era una práctica común que estas imágenes francesas circularan en revistas de otras partes del mundo, tanto en Europa como en Estados Unidos y Latinoamérica. En algunas ocasiones, las revistas extranjeras firmaban contratos con alguna editorial de Francia para comprar sus figurines. En otras, estos se copiaban localmente sin respetar la autoría de la imagen (Steele, 2018, p. 133), práctica que fue muy común. Estas nuevas imágenes eran mercancías a disposición de una gran cantidad de mujeres a cambio de un módico precio $\mathrm{y}$, para quienes las coleccionaban, podían constituir ideales con los que compararse.

En términos generales, los figurines representaban a las mujeres como maniquíes estáticos e inexpresivos, vestidos con ropas cuidadas, que se ambientaban en escenarios emblemáticamente femeninos: el interior doméstico, el jardín, el salón de baile. En el figurín, la identificación a la que se apelaba no se refería a individualidades: por no representar a nadie en particular, estos grabados representaban al ideal de mujer burguesa, anónima, con el que cualquier lectora de periódicos pudiera identificarse.

En el tercer número de La Flor del Aire aparece uno de los primeros figurines de esta época 
116 | Vestidos de papel: representaciones de la moda...

Figura 1

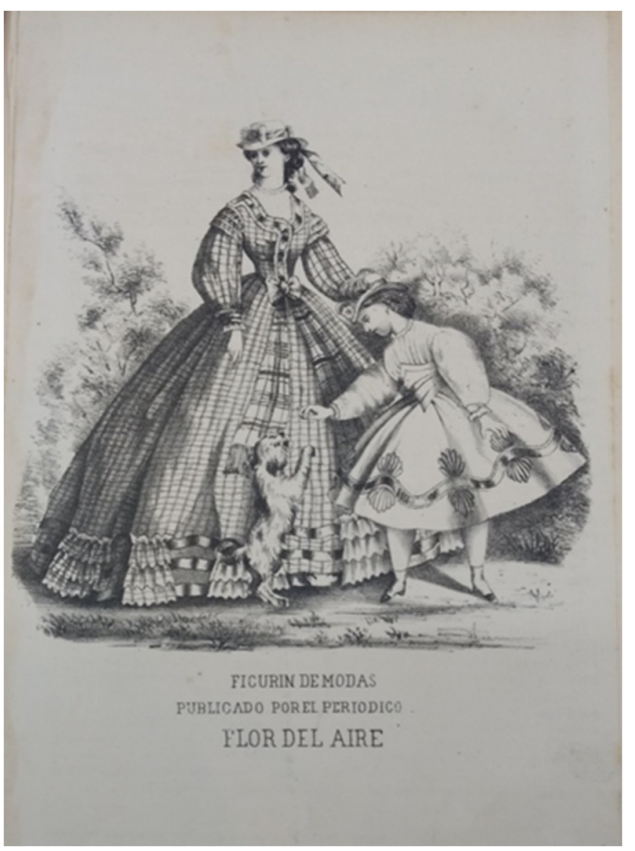

Fuente: La Flor del Aire, 17 de marzo de 1864, p. 19.

La descripción de este figurín, ubicada en la sección "Modas" de la revista, reza lo siguiente:

El figurín que acompaña este número de la Flor del Aire, es copiado del Monitor de la moda; el que nos dice que el sombrero es hecho por Mme Bernard, el vestido por Mme Slé-Llorain, que las guarniciones son de la Ville de Lyon; tienda de la Chaussée d'Antin, el corsé es de Mme Simon y las valencianas de J. Violard, en la calle de Choiseul, num. 5.

Todo eso está muy bien, pero es muy lejos y nosotros que vivimos en Buenos Ayres [sic] debemos sujetarnos á las modistas del país y ponerlas en voga [sic];

Una sociedad como la nuestra, cuyo círculo elegante es vasto, pero cuyo número de ricos es limitado; tiene que suplir la escasez de fortuna por el ingenio y la elegancia.

Las ricas que gasten -pero las pobres que se ingenien. ${ }^{6}$

Sin limitarse a describir llanamente la vestimenta, el texto brinda otra información sobre la imagen -señala que se trata de una copia de un figurín francés- y además busca adaptar aquella lejana moda europea ("todo eso está muy bien, pero es muy lejos”) a la realidad y circunstancias locales: una sociedad en la que se superponían viejas tradiciones con nuevas aspiraciones de modernidad; $y$ a la que cada día se incorporaban nuevos y diversos integrantes (Sábato, 2004, p. 45). Así, si teóricamente "abundaba el buen gusto", eran pocas quienes podían gastar mucho dinero a la hora de vestir. Por lo

${ }^{6}$ La Flor del Aire, 17 de marzo de 1864, pp. 24-25. 
tanto, explica la cronista, las mujeres debían "ingeniárselas" a fin de estar a la moda. Si comparamos este figurín con otros publicados en Le Moniteur de la Mode o Le Journal des Dames et Des Demoiselles durante la década de 1860, constatamos que las faldas muy amplias, acentuadas por medio de volados, los puños abullonados, los pequeños sombreros adornados con cintas en su parte posterior e inclusive el estampado cuadrillé de la tela estaban en boga en Europa desde 1859, lo que denota un cierto atraso en Buenos Aires respecto del viejo continente. ${ }^{7}$ Probablemente, la intención del texto haya sido reconocer en la imagen europea una forma idealizada de vestir, que, en un contexto como la Buenos Aires de 1864, no fuera necesariamente factible. Por lo tanto, si bien la ilustración francesa indicaba cómo debería lucir una mujer burguesa, el texto redactado en Buenos Aires procuraba adaptar esa moda extranjera a la realidad de las porteñas. Desde luego, esto no significa que las consumidoras de periódicos siguieran al pie de la letra esas formas. Con todo, la imagen impresa funcionaba como un ideal, no necesariamente alcanzable.

A su vez, no siempre los figurines eran importados: todos los publicados en la primera época del Correo del Domingo llevan las iniciales de Henry Meyer, litógrafo y dibujante francés que, como muchos compatriotas, se había instalado en Buenos Aires a mediados de la década de 1850. Meyer fue muy prolífico en su producción para el Correo del Domingo: la mayoría de las imágenes de este periódico llevan su firma. Además de los figurines de moda, Meyer producía vistas de edificios, escenas urbanas y retratos. En 1863 fundaría el popular periódico satírico El Mosquito, del que fuera también uno de sus primeros dibujantes (Román, 2017, pp. 36-38). En cuanto al modo de producción de las imágenes, existen pocas evidencias históricas que nos permitan conocer la cotidianeidad del trabajo de Meyer en el Correo del Domingo. En el caso de las vistas de edificios y los retratos de personajes célebres -imágenes cuya elaboración requería conocimientos específicos, trabajo en un taller con materiales difíciles de trasladar, etc.estos eran generalmente elaborados a partir de bocetos o dibujos más sencillos, realizados por dibujantes naturalistas (Szir, 2013). Las fuentes no nos permiten asegurar, en cambio, el modo de producción de estos figurines. Es probable que se tratara, al menos en parte, de copias de imágenes francesas. En algunos casos, la copia se explicita: una sola página con cuatro figurines distintos, con el título "modas" y el subtítulo "copia de los últimos figurines de París, hecha para el Correo del Domingo". 8

\footnotetext{
${ }^{7}$ Ejemplo de uno de los figurines de Jules David publicado en Le Journal des Dames et des Demoiselles, edition Belge, 1865, No. 787: Toilettes de la Mon Gagelin (...), A. Bodin, 1865. Colección digital de imágenes del Rijksmuseum, Amsterdam. Recuperado de: https://www.rijksmuseum.nl/en/collection/RP-P-2009-3495 (fecha de consulta: 06/09/2019).

${ }^{8}$ Correo del Domingo, 17 de abril de 1864, p. 217.
}

Anuario de la Escuela de Historia Virtual - Año 11 - N 18 - 2020: pp. 107-132. ISSN: 1853-7049 
118 | Vestidos de papel: representaciones de la moda...

\section{Figura 2}

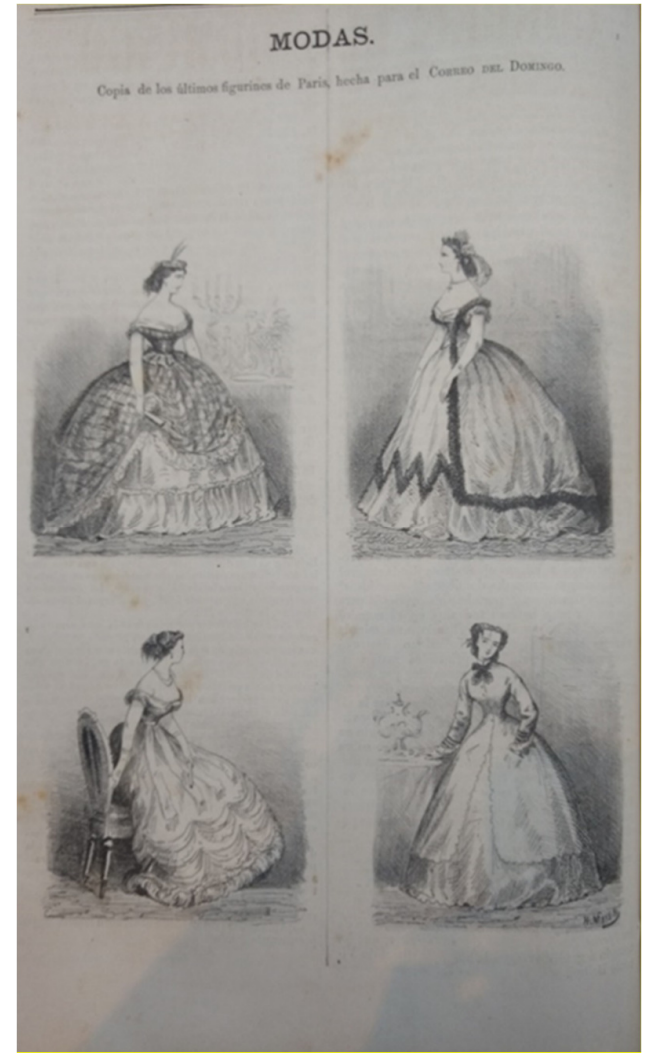

Fuente: Correo del Domingo, 17 de abril de 1864, p. 217.

Frecuentemente, en los figurines del Correo del Domingo el contexto está ausente o se esboza apenas mediante epígrafes que especifican los momentos ideales para usar cada vestido, con fórmulas del tipo "Traje de visita”, "Traje de paseo", “Traje de casa”, etc. Así, de acuerdo a estos epígrafes, visitar a alguien, realizar un paseo o incluso permanecer en el propio hogar, se presentaban como ocasiones para consumir vestimenta. Si bien está claro que el objetivo de los figurines era mostrar vestidos con el mayor detalle posible (Steele, 2018, p. 145), esas imágenes de moda eran, al mismo tiempo, imágenes de mujeres $\mathrm{y}$, en tal sentido, los figurines contribuyeron a la construcción de arquetipos de feminidad (Kackzan, 2012).

Estas ilustraciones recreaban visualmente actitudes femeninas asociadas a la intimidad, pero, al mostrarse en periódicos, se volvían públicas, configurando así modelos para los cuerpos femeninos y su comportamiento: con cada entrega, las imágenes iban construyendo un repertorio visual acerca de cómo debía verse y comportarse la mujer y qué poses y actitudes debía adoptar según la ocasión. Tanto dentro de su hogar como fuera de este, los figurines vinculan a las mujeres burguesas con actividades de ocio muy limitadas, que dan como resultado una reiteración de temas en las imágenes. 
Dentro de sus hogares, las mujeres aparecen inactivas: posan u observan sus propios vestidos en los espejos, como se observa a continuación en las figuras 3 y 4 :

\section{Figura 3}

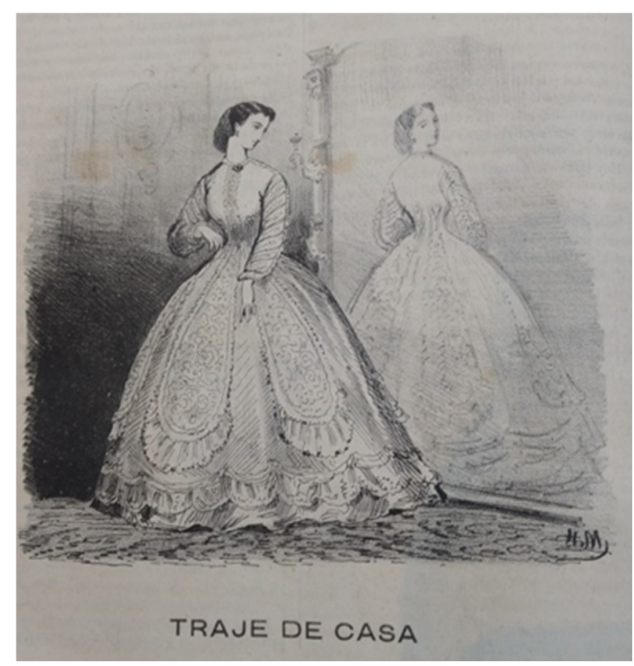

Fuente: Correo del Domingo, 21 de mayo de 1865, p. 576.

\section{Figura 4}

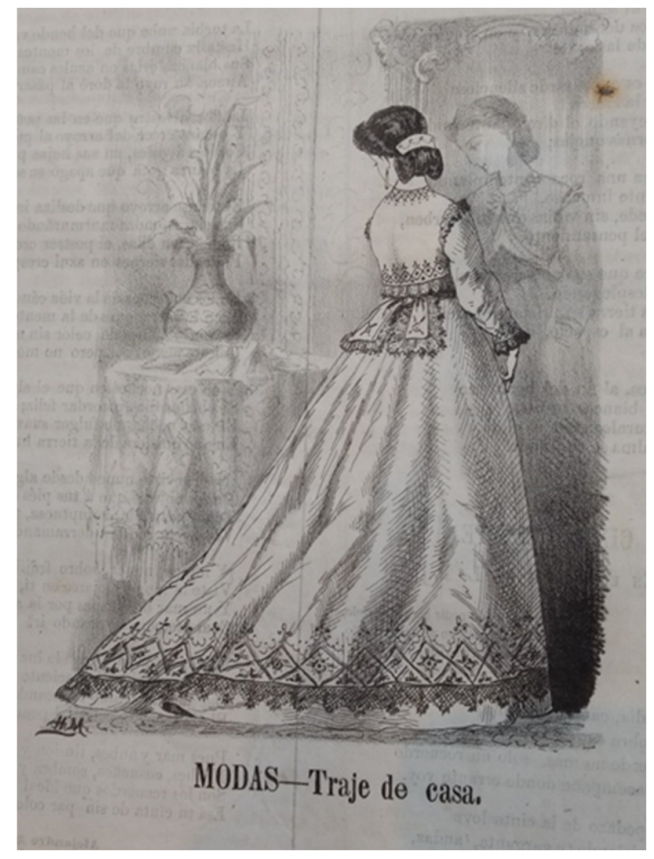

Fuente: Correo del Domingo, 7 de agosto de 1864, p. 384.

La gestualidad del rostro y las manos, como también las poses, siempre denotan delicadeza y algún grado de afectación. La presencia de espejos en varios figurines - 
120 | Vestidos de papel: representaciones de la moda...

tanto en copias como en originales importados- responde, al menos, a dos motivos: por un lado, a la creciente relevancia que estos objetos habían ido adquiriendo dentro de los hogares burgueses (Melchoir-Bonnet, 2001). En París, el espejo había comenzado a popularizarse a lo largo del siglo XVIII, adoptando distintas formas que iban desde miniaturas portables hasta enormes objetos enmarcados como los que se observan en los figurines. Por otra parte, en estas imágenes, los espejos pueden también haber funcionado como una estrategia de los artistas, ya que permitían mostrar un vestido de frente y de espaldas al mismo tiempo.

Hemos señalado que los figurines podían ser importados de París, o bien, copias de originales franceses. La Ondina del Plata parece haber recurrido a ambas prácticas: la importación y la copia/reproducción. Durante los dos primeros dos años de la revista 1875 y 1876- es posible identificar algunos figurines "iluminados" -tal era el adjetivo usado para referirse a los grabados a color. Dado que la colección no se encuentra completa, un análisis cuantitativo de las imágenes no arrojaría resultados confiables. A pesar de esta dificultad, para brindar una idea al lector, en los números disponibles correspondientes al año 1876 fueron relevados 11 figurines, de los cuales 6 son a color. En los números disponibles correspondientes a los tres años siguientes de la revista no se encontraron imágenes coloreadas y sí, en cambio, numerosos figurines en blanco y negro. Si bien La Ondina del Plata no brinda a sus lectoras una explicación para este cambio en el tipo de imágenes ofrecidas, lo más probable es que se tratara de una cuestión de costos.

Los figurines a color distribuidos llevan la firma de Jules David. Este artista francés se destacó particularmente en el campo de la ilustración de moda, produciendo aproximadamente 2.600 figurines a lo largo de casi medio siglo (Steele, 2018, p. 135). Además, las imágenes cuentan con un sello "Ad. Goubauld et Fils Edres. París", referido a Adolphe Goubaud, editor de Le Moniteur de la Mode, una de las revistas de moda francesas más difundidas, que contó con ocho ediciones extranjeras entre 1843 y 1892 (Steele, 2018, p. 136). Como se puede observar (figuras 5 y 6), se trata de imágenes sobrecargadas de detalles que recreaban lujosos contextos para estas mujeres siempre gráciles y ociosas. 
Figura 5

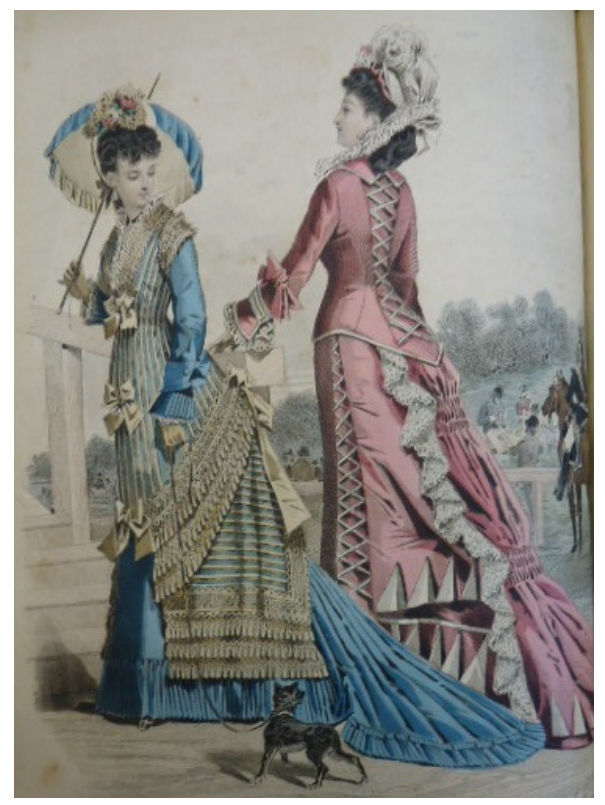

Fuente: La Ondina del Plata, 11 de junio de 1876, p. s/n.

Figura 6

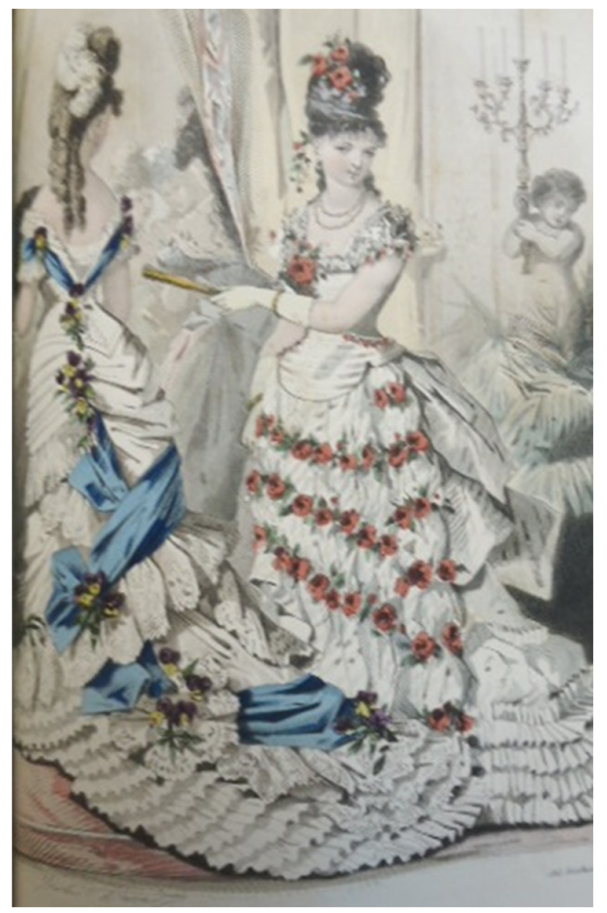

Fuente: La Ondina del Plata, 25 de noviembre de 1877, p. s/n. 
122 | Vestidos de papel: representaciones de la moda...

En el caso de los figurines en blanco y negro (fig. 7) es evidente que se trata de copias de imágenes francesas. En el extremo inferior izquierdo llegan a leerse las iniciales de Jules David, aunque su firma, presente en los figurines iluminados, no aparece. Otro indicio que refuerza la hipótesis de la copia es que, en la descripción del figurín, los colores están presentes, como si quien describe estuviera observando una imagen a color:

Para terminar, he aquí la descripción del figurín.

Traje de paseo- Vestido de cachemir azul marino con rayas de colores, falda de cola, rodeada de tableados. Delantal formando punto y recogido de un solo lado con un moño. Coraza con talle muy largo, con cordón alrededor. Sombrero redondo adornado de terciopelo azul, con el ala levantada por detrás, y encajes de hilo color crema.

$2^{\circ}$ Traje de gros ciruela y fular gris. Pollera de cola con varios volados plegados. Delantal redondo, con dos grandes puntas atadas atrás. Gorro bebé de color ciruela y adornado de rosa té y encajes color crema que se atan por delante. ${ }^{9}$

\section{Figura 7}

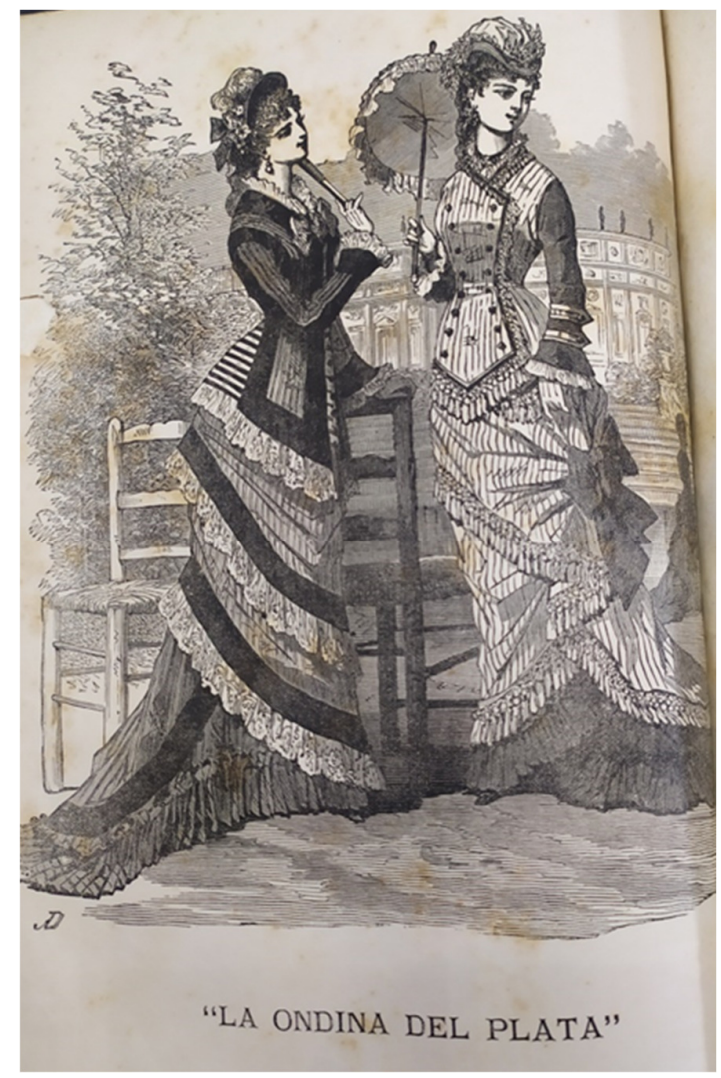

Fuente: La Ondina del Plata, 28 de mayo de 1876, p. 260.

\footnotetext{
${ }^{9}$ La Ondina del Plata, 28 de mayo de 1876, p. 263.
} 
Este tipo de descripciones fue muy común en La Ondina. La descripción no solo se refiere a las características del vestido hecho, sino que agrega detalles acerca de todos los materiales utilizados para la elaboración de cada pieza; y la manera en que estas eran confeccionadas. En tal sentido, es evidente que las descripciones de los figurines remitían a saberes sobre costura muy difundidos entre las lectoras y podían funcionar como instrucciones para transformar aquellas imágenes en vestimenta concreta. La relación entre texto e imagen, de todos modos, no siempre era sencilla, porque como ya hemos adelantado, el figurín establecía un ideal, no necesariamente alcanzable:

Al principio de la estación se pensó en dejar las sobrepolleras y pouffs, pues el número incalculable de varas de género que necesitaban y los precios excesivos de las hechuras, había acabado por asustar a las más medidas de entre nosotras: se quiso adoptar el vestido princesa que se usa mucho en París, pero que por ahora no se podrá usar aquí, pues esa forma se adapta a telas pesadas, y no a las livianas gazas [sic] y muselinas que tenemos que usar por los fuertes calores. ${ }^{10}$

En este párrafo, se explicitan los motivos por los cuales las modas de París no podían seguirse rigurosamente en Buenos Aires: a las razones económicas -vestidos que eran caros porque llevaban varias capas de tela- se sumaban las razones climáticas, ya que en el hemisferio norte siempre se estaba asistiendo a la estación opuesta. La crónica reubicaba el figurín francés en el contexto local, sugiriendo reemplazar las inaccesibles sobrefaldas que estaban de moda por delantales:

Yo por mi parte no desearía pasase la linda moda del delantal, cuando no es muy ajustado, pues lo usamos ya de tanto tiempo que cuando nos vemos vestidas con una sola pollera, creemos que algo nos falta, y que nuestro traje no es completo si no tiene dos polleras. ${ }^{11}$

En síntesis, los figurines nacionales e importados que distribuían estos periódicos fueron productos culturales cargados de significados, que se distribuyeron en publicaciones locales desde la década de 1860. Estas imágenes permitían conocer, de manera rápida y efectiva, las últimas novedades de la moda parisina; pero sus descripciones buscaban, en la medida de lo posible, adaptarlos a la realidad porteña. El seguimiento de los figurines a lo largo del tiempo nos permite, asimismo, observar las transformaciones de la moda en este periodo: durante la primera mitad de la década de 1860, la circunferencia de las faldas llegaba a su máxima dimensión, en forma de una cúpula lograda mediante el miriñaque y acentuada por medio de volados. En los vestidos correspondientes a la década de 1870, se observan continuidades y cambios: por un lado, la compresión del torso mediante corsé sigue muy presente, y esta prenda seguiría formando parte del vestuario femenino hasta al menos la primera década del

\footnotetext{
${ }^{10}$ La Ondina del Plata, 30 de enero de 1876, p. 56-57.

${ }^{11}$ Idem.
} 
124 | Vestidos de papel: representaciones de la moda...

siglo XX. ${ }^{12}$ Las faldas, en cambio, se angostan, y los miriñaques circulares, por su parte, son reemplazados por el "polisón", estructura también confeccionada en metal y tela, que se ataba a la cintura y colocaba volumen hacia la parte posterior del cuerpo, no ya en forma de circunferencia. ${ }^{13}$

\section{Sed de lujo, guerra al lujo}

Lo expuesto hasta aquí nos permite afirmar que, en los periódicos literarios ilustrados de esta época, la moda ocupó un lugar de considerable relevancia. La principal novedad de la prensa en relación a la moda en este periodo fue la inclusión de imágenes elaboradas específicamente para transmitir los estilos de vestimenta. Estas imágenes, atractivas y coleccionables, constituían poderosos dispositivos al momento de establecer ideales de belleza y elegancia para las mujeres que los consumían. Asimismo, al mostrar

permanentemente "las últimas modas" de París, estos figurines actuaban como estímulos para el consumo de vestimenta.

Sin embargo, los figurines convivieron con otros textos, referidos a los problemas que la moda podía traer para las familias porteñas. Existieron discursos que insistentemente reprobaban el consumo de ropa, entendido como un peligroso dispendio para las mujeres y sus familias. El Correo del Domingo, por ejemplo, consideraba al interés de las mujeres por la moda como algo "natural", pero advertía sobre los límites dentro de los cuales podía y debía adoptarse:

La moda puede reputarse como la espresión [sic] del deseo de agradar. Es este deseo tan natural en las mujeres, que, lejos de censurarlo, debiéramos aplaudirlo, siempre que se contenga en los justos límites y no invada el terreno de la afectación. ${ }^{14}$

Si la moda era la expresión del deseo de agradar, cabría preguntarse por qué ese deseo pertenecía únicamente a las mujeres, y a quién o quiénes querían agradar. Desde su lugar de editora en el periódico La Siempre Viva, Juana Manso reconocía en su primer número este interés femenino por la moda, en contraposición a otros que consideraba más virtuosos:

12 El uso del corsé estuvo sumamente extendido en el mundo occidental, a pesar de los discursos médicos que, en contextos de tuberculosis, advertían que esta prenda dificultaba la respiración y disminuía las defensas (Armus, 2007, pp. 235-246). No obstante, en la literatura victoriana la tuberculosis misma fue frecuentemente romantizada y asociada a una fragilidad, que era entendida como inherente a las mujeres. Para un estudio profundo sobre la relación entre moda y tuberculosis, ver: Day (2017).

${ }^{13}$ Ejemplares de este tipo de miriñaques y polisones se encuentran disponibles, por ejemplo, en el Kunstgewerbemuseum (Museo de Artes Decorativas de Berlín), Inv. 2003 - KR 319 a-g.

${ }^{14}$ Correo del Domingo, 13 de noviembre de 1864, p. 727. 
El hombre habla ciencias [sic], literatura, progreso; mientras que la muger [sic] habla modas, modas, modas; [...] en este estado de cosas, la civilización viene falseada por su base, porque ella no consiste en el lujo sino en las costumbres, consiste en la moral, en el progreso exterior de la sociedad como en su desarrollo intelectual [...] La mujer del cristianismo, la mujer de la civilización, no ha nacido para vivir entre una crinolina y una cresta, con un espejo por delante: su verdadero destino, su destino de mujer, es amar, sufrir y perdonar, pero también es adquirir por medio de la educación, virtudes con que desempeñar los serios deberes de esposa y de madre. ${ }^{15}$

Si bien Juana Manso admite que las mujeres se interesan por la moda y que, por lo tanto, es lógico que hablen de ello, advierte cuáles deberían ser sus intereses en relación a "su verdadero destino": ser una buena esposa y una buena madre, acompañar dignamente a su marido y educar apropiadamente a su descendencia. En otras publicaciones, como el Álbum del Hogar, se daba por sentado que las mujeres eran sujetos frívolos, y que la moda era parte central de sus preocupaciones. Estas escrituras banales asumían su propia trivialidad sin mayores miramientos, e inclusive hacían alarde de ella (Rodríguez Lehmann, 2013, p. 84). Un ejemplo es este diálogo entre dos amigas, en el que se expresa con soltura que la mayoría de las mujeres estarían dispuestas a morir si la moda así lo dictase:

-Yo creo firmemente que si mañana la moda nos mandase ahorcarnos, pocas, muy pocas sobreviviríamos a la catástrofe.

-Inclinémonos, pues, ante nuestra augusta reina y señora, cuya soberbia magestad [sic] no admite excepciones a la obediencia. ${ }^{16}$

Aquí la moda aparece como una reina severa, que ordena lo que las mujeres deben hacer y cuya obediencia no se discute. Además, se naturaliza por completo la pasión de las mujeres por el consumo de "chucherías" destinadas a realzar su propia apariencia:

¿Acaso hay una sola de nosotras que mire con indiferencia el espejo, los perfumes, los adornos, las cintas, las joyas, y todas esas encantadoras chucherías de la moda, que muchas veces nos hacen perder el sueño? ${ }^{17}$

Esta pasión de las mujeres por la vestimenta, que los periódicos presentan como "natural", era, en realidad, el resultado de una serie de códigos sociales que le exigían lucir de determinada forma. Y ese "cómo lucir" era también finamente entrenado desde la visualidad, a través de imágenes como los figurines.

A pesar de contener secciones específicas dedicadas a la moda y de distribuir figurines importados de París, La Flor del Aire y La Ondina del Plata aseguraban ser "opositoras del lujo":

\footnotetext{
${ }^{15}$ La Siempre Viva, 16 de junio de 1864, p. 1.

${ }^{16}$ El Álbum del hogar, 14 de julio de 1878, p. ilegible.

${ }^{17}$ El Álbum del Hogar, 7 de julio de 1878, p. 4.
} 
126 | Vestidos de papel: representaciones de la moda...

Nos declaramos desde nuestra aparición como cronistas de la moda, opositoras del lujo; la ostentación es el aparsagio [sic] de las viejas y de las feas, las niñas, las mugeres [sic] lindas no necesitan empobrecer a sus padres, a sus maridos y lo que es peor todavía, asustar a sus

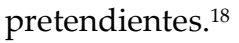

La ostentación, expresada a través de la moda, no solo era "de mal gusto", sino que implicaba gastos que recaían en padres y esposos, y que si eran excesivos podrían traer como consecuencia el alejamiento de posibles pretendientes. No obstante, para conocer y atraer a esos pretendientes, había que mostrarse bien vestida. Entendidos de esa forma, los vestidos y demás accesorios elegantes funcionaban como objetos de mediación, claves al momento de vincularse con otras personas y de sostener dichos vínculos (Douglas e Isherwood, 1990, p. 18). La moda era, para las mujeres, un modo lícito de expresión, siempre y cuando se expresara en su justa medida. Ataviarse de una forma demasiado llamativa podía, o bien deslumbrar a los hombres o, por el contrario, ahuyentarlos ante la posibilidad de caer en la ruina si elegían a esa mujer como su esposa.

En una contratapa del Correo del Domingo se representa una escena en la que, ante el reclamo del hombre "cuando no son bailes son conciertos, y por resultado todo son gastos y desorden", la mujer responde que es preciso que ella vaya "a todas partes" con el objetivo de presentar en sociedad a la niña y que esta, por lo tanto, eventualmente se case (fig. 8). Los bailes, que en estas décadas se realizaban en espacios como el Club del Progreso (González Bernaldo, 2000), eran ocasiones ideales para consumir vestimenta, ya que la misma constituía el apoyo necesario para lucir adecuadamente (Roche, 2000, p. 80). Aquí, se pone de manifiesto la tensión entre los gastos, que el hombre de la casa debería controlar, y la necesidad de que las mujeres asistan a bailes y conciertos si querían ser reconocidas como parte de determinado círculo social. Cierto es que el interés por concretar un matrimonio conveniente no era solo femenino, ${ }^{19}$ pero las fuentes insisten en que eran las mujeres quienes tenían que invertir dinero y tiempo en la construcción de una apariencia, con el objetivo de casarse. Así, en definitiva, el gasto en prendas de vestir podía ser interpretado como una inversión, necesaria para asegurar un buen futuro. La Flor del Aire, en su primer número, también condenaba al lujo, pero aseveraba que la moda era útil para las mujeres al momento de procurarse un matrimonio conveniente:

[...] Venimos a poner en voga [sic] los géneros al alcance de todos, realzados por la elegancia y el buen gusto; venimos a hacer una gran revolución, lo prevenimos. El imperio de la muger [sic] es la moda; pero no tiránica y costosa, sino fácil, lijera [sic] y graciosa; no

\footnotetext{
${ }^{18}$ La Flor del Aire, 3 de marzo de 1864, p. 7.

${ }^{19}$ El protagonista de la célebre novela En la Sangre, de Eugenio Cambaceres (1887), era Genaro Piazza, un muchacho pobre, hijo de inmigrantes italianos, que aspiraba a ascender socialmente por la vía matrimonial.
} 
ruina que oprime, sí anzuelo, harpón [sic], lazo, con que pescar corazones y sobre todo.... maridos! ${ }^{20}$

\section{Figura 8}

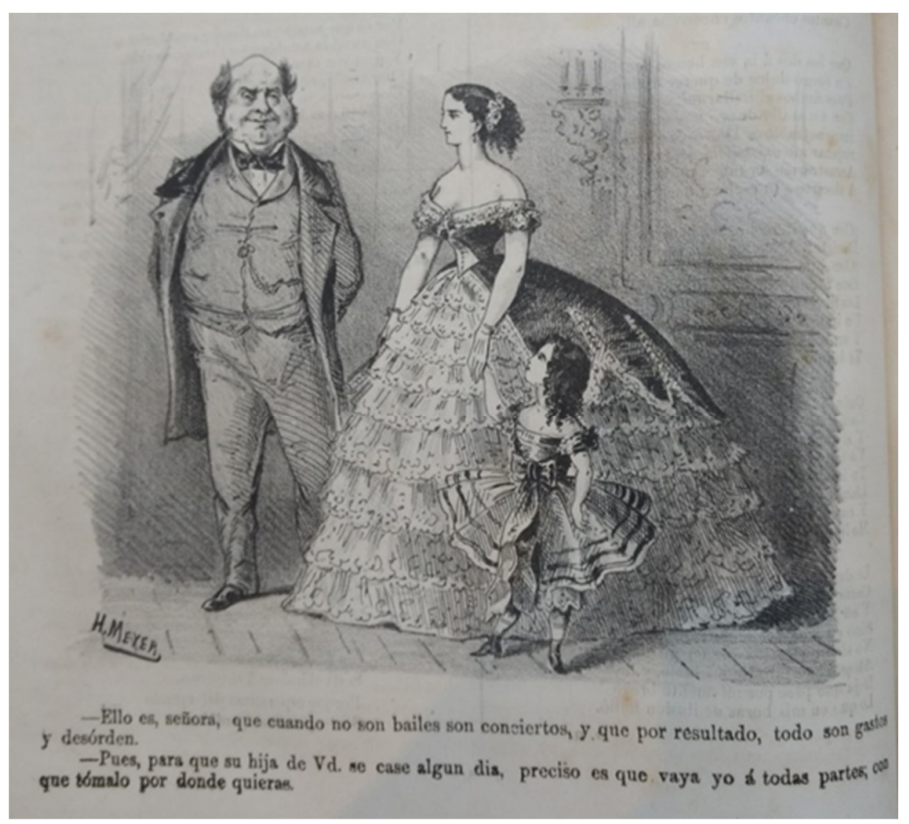

Fuente: Correo del Domingo, 17 de abril de 1864, p. 215.

Además, el texto propone una moda "fácil y ligera", con "géneros al alcance de todos", y resalta "la elegancia" y "el buen gusto" como valores de aquellas personas que no necesitan gastar demasiado para vestirse bien. En La Ondina del Plata las descripciones de costosos trajes, unidas a los figurines coloreados, se ponen en tensión con textos que insisten sobre los peligros del consumo conspicuo. Aquí también se mencionan como valores "la elegancia" y "el buen gusto", al tiempo que se propone, como alternativa, el uso de telas sencillas y económicas:

Los trajes más en moda hoy, son los de percal. ¿Habéis visto esos trajes hechos con elegancia y buen gusto cuán preciosos son? [...] A mí me agradan en estremo [sic] pues se hallan resumidos en ellos la sencillez y la economía: Dios quisiera que se adoptasen telas como esta, de poco precio, para así derrotar al más terrible enemigo de la mujer: el lujo, que tantos sacrificios cuesta a padres y esposos [...] Sí, queridas mías, iguerra al lujo! iguerra a esa mísera vanidad!21

En La Alborada del Plata, un largo texto de Lola Larrosa también advertía sobre esta cuestión y responsabilizaba a las mujeres por los gastos excesivos en ropa:

${ }^{20}$ La Flor del Aire, 3 de marzo de 1864, p. 7,

${ }^{21}$ La Ondina del plata, 19 de marzo de 1876, p. 142.

Anuario de la Escuela de Historia Virtual - Año 11 - N 18 - 2020: pp. 107-132. ISSN: 1853-7049 
128 | Vestidos de papel: representaciones de la moda...

[...] Hoy todo se sacrifica al lujo, a las diversiones.

El lujo, que no es censurable cuando no pasa los límites regulares [...] pero que llevado hasta el extremo, puede causar desgracias irreparables. Cada cual debe vestir con arreglo a su posición; pero no esponer [sic] entre modistas y comerciantes la fortuna, y hasta la honra de la familia [...]

Un aderezo, un traje de baile, son muchas veces [...] la base de grandes catástrofes; la exageración del lujo da por resultado las deudas y las discusiones con el esposo, que ve aterrado tal desorden [...] se puede vestir con lujo y sencillez, con buen gusto, sin despilfarro. [Es posible] vestirse con el decoro [de] su posición, la de su esposo y la de su nombre $[\ldots]$ no aspirando la de humilde esfera á igualarse á la de elevada clase". ${ }^{22}$

La preocupación por la economía familiar -en la que las principales víctimas eran los padres y esposos- fue un tema recurrente. Para Larrosa, la mujer es la responsable: debe poseer "gran tacto" y "decoro" al momento de comprar y usar la vestimenta, pues si gasta demasiado con el objetivo de parecer más rica de lo que realmente es, termina discutiendo con su esposo y endeudando a su familia. Además, la afirmación "se puede vestir con lujo y sencillez" constituye prácticamente un oxímoron, si tenemos en cuenta que para que un producto sea considerado lujoso, debe ser al mismo tiempo exclusivo para unos pocos y objeto de deseo de muchos (Berry, 1994, pp. 27-31). En todo caso, a estas publicaciones les resultaba necesario advertir respecto de las tentaciones que el consumo de moda implicaba, pues este podía dar como resultado la ruina familiar, la pérdida de la honradez e inclusive de la cordura. No tenía sentido ostentar "hacia afuera" cuando había otras necesidades en el hogar, "hacia adentro":

Por ostentar un costoso traje ¡qué privaciones tendrá que sufrir el interior del hogar! Todos los días tienen disgustos con sus maridos porque estos no pueden satisfacer sus exigencias, esa inagotable sed de lujo.

Se ven a menudo mujeres muy pobres [...] que sin embargo se atavían cual si fuesen personas de fortuna: desatienden las necesidades más preciosas y si es posible, hasta el alimento, ¿y por qué? Por vanidad.

[...] Debéis considerar que con la misma elegancia que llevais un traje de moiré ó terciopelo, podéis llevar uno de popelina ó cualquier otra tela de buen gusto y poco costo, teniendo la proporción de un periódico tan barato como es la Ondina, que mensualmente os obsequia con el último figurín de moda; y podéis guiaros de los cortes y no de las telas por ser estas a veces de mucho costo. ${ }^{23}$

En este caso, una vez más, se condena la "sed de lujo" de las mujeres vanidosas que no pueden permitírselo, y se ofrece como alternativa confeccionar los mismos modelos presentados en los figurines, pero usando telas más económicas. La autoconfección se presentó, en reiteradas oportunidades, como una alternativa para consumir vestimenta de moda sin llegar al punto del derroche:

${ }^{22}$ La Alborada del Plata, 25 de enero de 1880, p. ilegible.

${ }^{23}$ La Ondina del plata, 2 de abril de 1876, p. 166. 
Parece superfluo insistir [...] sobre la necesidad que se impone, cuando se carece de recursos abundantes, de que la muger [sic] trabaje por sí misma en sus trajes, porque la confección es cada día más dispendiosa. Hoy no es solamente en las familias que disponen de recursos medianos que la muger [sic] debe esforzarse en ser su propia costurera [...] Toda muger [sic] que no pueda vivir en la opulencia, será una causa de ruina para su familia, sino ha aprendido á cortar y á coser por sí misma los trajes que deben servirla. ${ }^{24}$

Así, junto a la advertencia, se ofrece una alternativa: la autoconfección era el mejor camino para vestir elegantemente sin gastar demasiado. En este caso, se sugiere que cada mujer elabore sus propios trajes y, de esa forma, ahorre el dinero correspondiente a las modistas. Para concretar la hechura, además de las descripciones de los figurines a las que ya nos hemos referido, publicaciones como La Flor del Aire ofrecían moldes con instrucciones para la elaboración de prendas. Asimismo, circulaban en Buenos Aires revistas extranjeras -como la española La Torre de Oro- que contaban con innumerables moldes de prendas y detalladas indicaciones para su confección. La clave, en todo caso, no estaba en ignorar o dejar de lado las modas, sino en ser capaces de reproducirlas, a pesar de no contar con recursos suficientes para ello.

\section{Reflexiones finales}

La revolución en la prensa, que tuvo lugar desde la década de 1860, otorgó a la moda un lugar renovado y preponderante. Nuevos periódicos la incluían entre sus temas de interés, que se expresaba tanto a través de textos escritos como de imágenes nacionales e importadas. Estas representaciones de la moda en su conjunto se dirigían exclusivamente a las mujeres, un nuevo nicho de consumidoras de periódicos.

Los figurines fueron poderosas imágenes, capaces de transmitir no solo qué vestidos estaban en boga cada temporada, sino también de comunicar todo un estilo de vida burgués, vinculado al ocio y el consumo conspicuo. Estas imágenes, artefactos culturales de una época en la que la visualidad cobraba cada vez más relevancia dentro de la prensa, se esperaban con ansiedad, se coleccionaban y circulaban por ciudades tan distintas entre sí como París, Buenos Aires y Río de Janeiro. En Buenos Aires, los figurines franceses fueron interpretados como modelos, no siempre concretables, pero que había que esforzarse por alcanzar.

Sin embargo, numerosos textos condenaban el consumo de vestimenta. Los mismos periódicos que distribuían figurines con "las últimas novedades de París" advertían también sobre los peligros que el gasto excesivo podría traer para las mujeres y sus familias. La moda se presenta, alternativamente, como una reina severa, como una

${ }^{24}$ El Álbum del hogar, 28 de julio de 1878, p. ilegible. 
130 | Vestidos de papel: representaciones de la moda...

debilidad "naturalmente" femenina y también como una herramienta útil, a la que las mujeres podían recurrir con el objetivo de atraer posibles pretendientes.

En definitiva, a través del análisis de las publicaciones, es posible identificar tensiones entre textos e imágenes. Mientras los figurines mostraban mujeres burguesas ociosas, despreocupadas, que vivían en la opulencia, se miraban al espejo o asistían a carreras adornadas para ser vistas, los textos, por su parte, señalaban los peligros que la moda podría acarrear. Asimismo, estos instaban a las mujeres a confeccionar su propia vestimenta, con telas más económicas. Estas sugerencias tendientes al ahorro, advertían que el consumo excesivo de vestimenta podía traer consecuencias negativas para las familias cuya economía no pudiera permitírselo. Con todo, las representaciones de la moda en la prensa porteña de este periodo fueron a menudo ambivalentes: en una sociedad que se encontraba en plena renovación, la moda se revelaba, al mismo tiempo, como síntoma y vehículo de sus reconfiguraciones.

\section{Referencias bibliográficas}

Armus, D. (2007). La ciudad impura. Salud, tuberculosis y cultura en Buenos Aires (18701950). Buenos Aires: Edhasa.

Baldasarre, M. (2019). El hábito hace al monje. Indumentaria, pose y autorrepresentación en fotos de artistas. En N. Altrudi y C. Vanegas Carrasco (Orgs.). El taller de Collivadino (pp. 70-87). San Martín: UNSAM Edita.

Baldasarre, M. (2020). Fantasías parisienses y sastrerías londinenses. Moda, comercio y publicidad en Buenos Aires a fines del siglo XIX. dObra[s], Revista da Associação Brasileira de Estudos de Pesquisas em Moda, 14 (29), 270-293.

Bard, C. (2012). Historia política del pantalón. Buenos Aires: Tusquets.

Batticuore, G. (2017). Lectoras del siglo XIX. Imaginarios y prácticas en la Argentina. Buenos Aires: Edhasa.

Berry, C. (1994). The idea of luxury. A conceptual and historical investigation. Cambridge: Cambridge University Press.

Caimari, L. (2015). El mundo al instante. Noticias y temporalidades en la era del cable submarino (1860-1900). Redes, Revista de Estudios sociales de la ciencia y la tecnología, 21 (40), 125-146.

Cambaceres, E. (1887). En la Sangre. Buenos Aires: Sudamericana.

Day, C. (2017). Consumptive chic. A History of Beauty, Fashion and Disease. Londres: Bloomsbury.

Douglas, M. e Isherwood, B. (1990). El mundo de los bienes. Hacia una antropología del consumo. México: Grijalbo.

Entwistle, J. (2002). El cuerpo y la moda. Una visión sociológica. Barcelona: Paidós.

Goldgel, V. (2013). Cuando lo nuevo conquistó América. Prensa, moda y literatura en el siglo XIX. Buenos Aires: Siglo XXI.

González Bernaldo, P. (2000). Civilidad y política en los orígenes de la Nación Argentina. Las sociabilidades en Buenos Aires, 1829-1862. Buenos Aires: Fondo de Cultura Económica. 
Hallstead, S. (2008). De los peinetones a las grandes tiendas: consumo e identidad en Argentina (1830-1880). En M. Moraña (ed.), Cultura y cambio social en América Latina (pp. 179-206). Madrid: Iberoamericana.

Hora, R. (2010). Historia económica de la Argentina en el siglo XIX. Buenos Aires: Siglo XXI.

Hora, R. y Losada, L. (2011). Clases altas y medias en la Argentina. Notas para una agenda de investigación. Desarrollo Económico, 50 (200), 611-630.

Iglesia, C. y Zuccotti, L. (1997). El estilo democrático: último grito de la moda. Mora. Revista del área interdisciplinaria de estudios de la mujer (3), 64-73.

Kackzan, G. (2012). Figuras femeninas en la mira. Cuerpos, vestidos, imágenes en las primeras dos décadas del siglo XX. Mora Revista del área interdisciplinaria de estudios de la mujer (18), 11-28.

Malosetti Costa, L. y Gené, M. (Eds.) (2013). Atrapados por la imagen. Arte y política en la cultura impresa argentina. Buenos Aires: Edhasa.

Manzano, V. (2009). The Blue-Jean Generation: Youth, Gender, and Sexuality in Buenos Aires, 1958-1975. Journal of Social History, 42 (3), 657-676.

Marin, L. (1993). Des pouvoirs de l'image. Gloses. Paris: Seuil.

Marino, M. (2009). Los peinetones de Bacle por las calles de Buenos Aires. En L. Malosetti Costa y M. Gené (Eds.). Impresiones porteñas. Imagen y palabra en la historia cultural de Buenos Aires (pp. 33-46). Buenos Aires: Edhasa.

Marino, M. (2013). Impresos para el cuerpo. El discurso visual del rosismo y sus inscripciones en la construcción de la apariencia. En L. Malosetti Costa y M. Gené (Eds.). Atrapados por la imagen. Arte y política en la cultura impresa argentina (pp. 19-45). Buenos Aires: Edhasa.

Melchoir-Bonnet, S. (2001). The Mirror, a History. Londres y Nueva York: Routledge.

Miguez, E. (2008). Historia económica de la Argentina. De la conquista a la crisis de 1930. Buenos Aires: Sudamericana.

Mirzoeff, N. (2003). Una introducción a la cultura visual. Buenos Aires: Paidós.

Milanesio, N. (2017). Descamisados, divitos y mucamas: la vestimenta como expresión de estereotipos y preocupaciones de clase durante el peronismo. En S. Hallstead y R. Root (Comps.). Pasado de moda. Expresiones culturales y consumo en la Argentina (pp. 188-200). Buenos Aires: Ampersand.

Mitchell, W.J. (1996). Teoría de la imagen. Madrid: Akal.

Nelson Best, K. (2019). El estilo entre líneas. Una historia del periodismo de moda. Buenos Aires: Ampersand.

Prieto, A. (2006). El discurso criollista en la formación de la Argentina moderna. Buenos Aires: Siglo XXI.

Roche, D. (2008). La cultura material a través de la historia de la indumentaria. En H. Gortari y G. Zermeño (Eds.). Historiografía francesa: Corrientes temáticas y metodológicas recientes. México: Centro de estudios mexicanos y centroamericanos.

Rodríguez Lehmann, C. (2017). Miradas efímeras. Cultura visual en el siglo XIX. Santiago de Chile: Editorial Cuarto Propio.

Rodríguez Lehmann, C. (2013). Con trazos de seda. Escrituras banales en el siglo XIX. Caracas: Fundavag.

Rodríguez Pérsico, A. (2003). Juan Bautista Alberdi: nación y razón. En J. Schvartzman (Dir.). Historia Crítica de la Literatura argentina, t. 2. Buenos Aires: Emecé. 
132 | Vestidos de papel: representaciones de la moda...

Román, C. (2010). La modernización de la prensa periódica, entre La patria argentina (1879) y Caras y Caretas (1898). En A. Laera (Comp.). Historia crítica de la literatura argentina, vol. 3: El brote de los géneros. Buenos Aires: Emecé.

Román, C. (2017). Prensa, política y cultura visual. El Mosquito (Buenos Aires, 1863-1893). Buenos Aires: Ampersand.

Root, R. (2014). Vestir la nación. Moda y política en la Argentina poscolonial. Buenos Aires: Edhasa.

Sábato, H. (2004). La política en las calles. Entre el voto y la movilización. Buenos Aires, 18621880. Bernal: Universidad Nacional de Quilmes. +

Sarmiento, D. F. (2010 [1887]). Obras Completas, vol. 1-7. Buenos Aires: Universidad Nacional de La Matanza.

Saulquin, S. (1990). La moda en la Argentina. Buenos Aires: Emecé.

Steele, V. (2018). Fashion Theory. Hacia una teoría cultural de la moda. Buenos Aires: Ampersand.

Szir, S. (2009). De la cultura impresa a la cultura de lo visible. Las publicaciones periódicas ilustradas en Buenos Aires en el siglo XIX. Colección Biblioteca Nacional. En H. M. Garabedian, S. M. Szir y M. Lida, Prensa Argentina siglo XIX. Imágenes, textos y contextos. Buenos Aires: Teseo.

Szir, S. (2013). Reporte documental, régimen visual y fotoperiodismo. La ilustración de noticias en la prensa periódica en Buenos Aires (1850-1910). Caiana, Revista de Historia del Arte y Cultura Visual del Centro Argentino de Investigadores del Arte, 3, 1-16.

Vicens, M. (2014). Pasiones prohibidas: lectoras, consumo y periodismo en la Argentina de 1880. Badebec, 4 (7), 85-108.

Zambrini, L. y Lucena, D. (2019). Costura y cultura. Aproximaciones sociológicas sobre el vestir. La Plata: EDULP.

Para citar este artículo:

Garabana, Teresita (2020). Vestidos de papel: representaciones de la moda en la prensa de Buenos Aires, décadas de 1860 y 1870. Anuario de la Escuela de Historia Virtual, 18, 107-132. 